\title{
A Study on Ethnobotanically Important Plant Species Used against Various Gastro-Intestinal (GI) Disorders by the Indigenous People of Barpeta District of Assam, North-East India
}

\author{
JyotirmoyThakuria $^{1, *}$, ManalishaDeka ${ }^{2}$, BijitaPodder $^{3}$ \\ ${ }^{1}$ Department of Molecular Biology and Biotechnology, Tezpur University, Tezpur-784028, Assam, India \\ ${ }^{2}$ Department of Zoology, BBK College, Barpeta-781311, Assam, India \\ ${ }^{3}$ Department of Microbiology and Biotechnology, MS University, Vadodara-390002, Gujarat, India
}

Received September 30, 2020; Revised November 7, 2020; Accepted November 29, 2020

\section{Cite This Paper in the following Citation Styles}

(a): [1] Jyotirmoy Thakuria, Manalisha Deka, Bijita Podder , "A Study on Ethnobotanically Important Plant Species Used against Various Gastro-Intestinal (GI) Disorders by the Indigenous People of Barpeta District of Assam, North-East India," Advances in Zoology and Botany, Vol. 8, No. 6, pp. 512 - 520, 2020. DOI: 10.13189/azb.2020.080605.

(b): Jyotirmoy Thakuria, Manalisha Deka, Bijita Podder (2020). A Study on Ethnobotanically Important Plant Species Used against Various Gastro-Intestinal (GI) Disorders by the Indigenous People of Barpeta District of Assam, North-East India. Advances in Zoology and Botany, 8(6), 512 - 520. DOI: 10.13189/azb.2020.080605.

Copyright $@ 2020$ by authors, all rights reserved. Authors agree that this article remains permanently open access under the terms of the Creative Commons Attribution License 4.0 International License

\begin{abstract}
Plants and plant products have been used in traditional medication system to treat several human diseases since long back. The North-eastern region of India is a part of foot hills of Himalayas and Indo-Burma biodiversity hot spot and it was proved to be a home for a large number of ethnoboanically important plant species by several researchers. The present study was carried out during July, 2018 to June, 2019 for a period of one year at Barpeta district of Assam, North-East India to prepare a database on traditional knowledge of indigenous people regarding the uses of different plants to cure various Gastro-Intestinal (GI) disorders. The district is situated at a global position between $26^{\circ} 45^{\prime}-26^{\circ} 50 \mathrm{~N}^{\prime}$ latitude and $90^{\circ} 30^{\prime}-91^{\circ} 51^{\prime} 0^{\prime \prime} \mathrm{E}$ longitude. Extensive field studies were conducted in the study area to obtain firsthand information on uses of ethnobotanically important plants. Sample specimens were collected and preserved during the study period. This report has documented 55 number of plant species belonging to 38 families used by the local people and especially by the traditional drug practitioners of the study area against various GI anomalies. In spite of the availability and accessibility of the modern system of medication, most of the people of the study area still depend on herbal medication system provided by
\end{abstract}

traditional drug practitioners to treat a range of GI anomalies. This documentation will help to harness this traditional knowledge and to preserve this knowledge for the betterment of future mankind.

Keywords Ethnobotany, Gastro-Intestinal (GI) Disorders, Traditional Medication

\section{Introduction}

Plants and plant products have been used as medicine to treat several human diseases since long ago. In a country like India, the traditionally used medication system plays an important role in health care of rural people. About 45000 number of plant species were recorded and identified In India and out of which more than 35000 plant species have been claimed to possess medicinal properties [1]. According to World Health Organization, about 80\% of the World's population especially the tribal and rural dwelling population depends on herbal medications for their primary health care needs [2].

The North-eastern region of India is a part of foot hills 
of Himalayas and Indo-Burma biodiversity hot spot and it comprises about $50 \%$ of India's total biodiversity [3]. Several researchers have studied about the ethnobotanically important plant species of this region at different times [4-7]. Assam is one of the evergreen states of North-East India and more than 200 medicinally important plant species were reported from this state [8].

Gastro-intestinal (GI) disorders are those which are associated with the gastro-intestinal tract and its associated glands viz., liver, pancreas etc. Diseases like dysentery, diarrhea, constipation, indigestion, stomach ache, stomach ulcer, worm infestation in children, piles, acidity or gastric trouble, Jaundice etc. are considered as GI disorders. The primary objective of the present study was to prepare a database on indigenous knowledge on medicinal plants used for curing various Gastro-Intestinal ailments of human beings among local people of Barpeta district of Assam, North-East India.

\section{Materials and Methods}

\subsection{Study Area}

The present study was carried out at Barpeta district of Assam, North-East India (Fig.1). The district is situated at a global position between $26^{\circ} 45^{\prime}-26^{\circ} 50 \mathrm{~N}^{\prime}$ latitude and $90^{\circ} 30^{\prime}-91^{\circ} 51^{\prime} 0^{\prime \prime} \mathrm{E}$ longitude. Barpeta district of Assam is bounded by Nalbari district to the East, Bongaigaon \& Chirang district to the West, Baska district to the North and Goalpara \& Kamrup district to the South. The district headquarter, Barpeta town is located at a distance of about $105 \mathrm{~km}$ from the state capital, Guwahati city. The district covers an area of 2645 sq. km with a total population of 1693622 (2011 census) and is having a total of 850 revenue villages [9]. The climatic condition of the area is subtropical with an annual average rainfall of 200-300 cm. This area is very rich in floral bio resources [10].

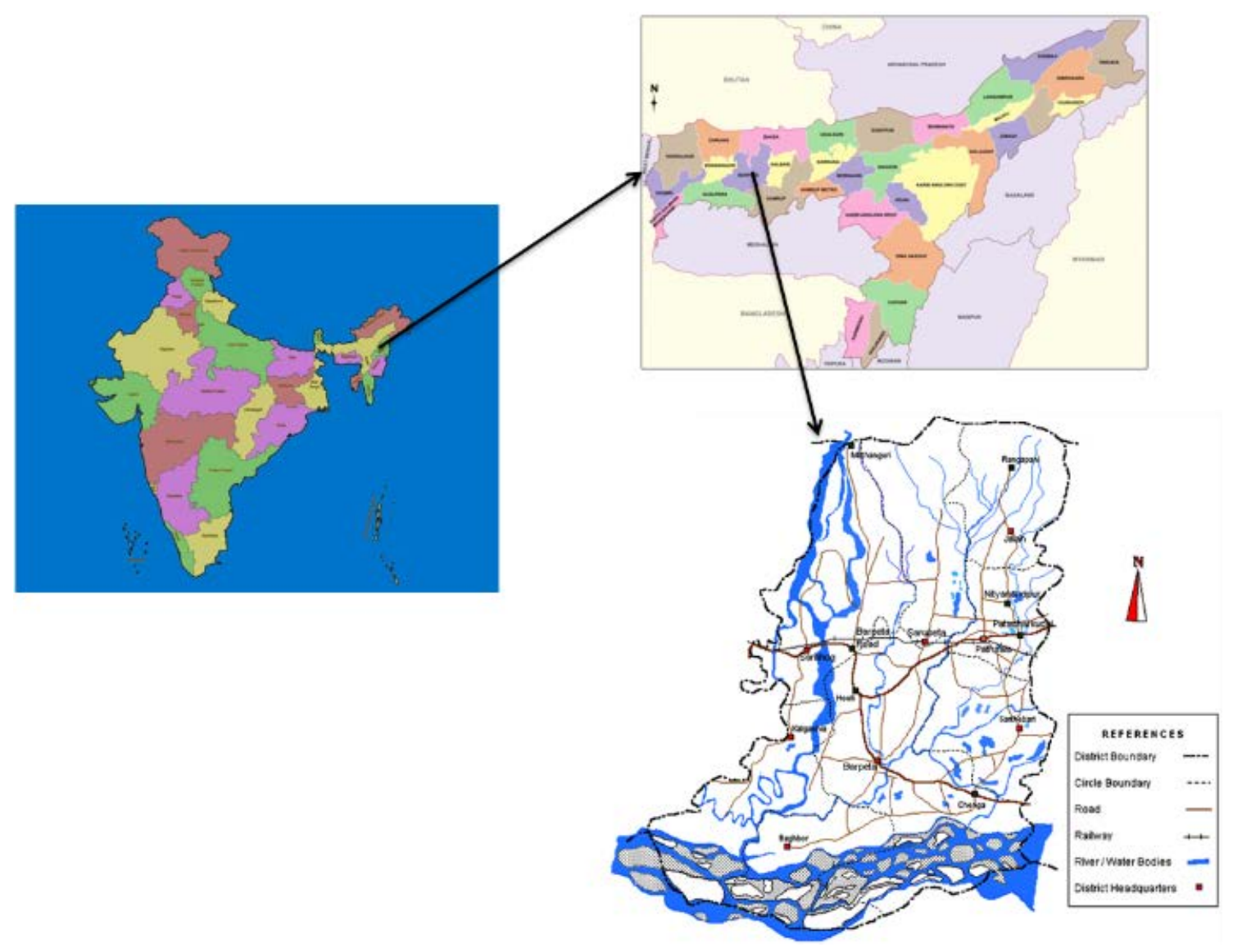

Figure 1. Map of the Study Area 


\subsection{Conduction of Survey, Sample Collection and Identification}

An extensive field study was carried out among the local people of the study area for a period of one year from July, 2018 to June, 2019. Simple random sampling method was adopted to conduct the survey. Basically, local traditional drug practitioners (locally known as Kabiraj or Bez) along with elderly people of age ranges between 40-90 years were interviewed for first-hand information regarding the use of different plants, mode of drug preparation and dosage composition which they use to cure Gastro-Intestinal anomalies. A total of 45 numbers of traditional drug practitioners (Kabiraj or Bez) were interviewed during the survey period.

The sample collection was done at the study sites by following standard protocol for plant collection. For collection of plant samples, study area was visited along with the respective Kabiraj or Bez from whom the information was recorded. Plant samples were collected in the flowering state and were kept in care. Collected plant samples were further processed and preserved following the routine protocol of standard herbarium preparation. Identification of the collected specimens were done with the help of pertinent floras [11-13] as well as with the help of taxonomic expert and confirmed with the authentic specimens present at the Botany Department, Gauhati University and Botanical Survey of India, Eastern Circle, Shillong, Meghalaya, India.

\section{Result}

A total 55 number of plants belonging to 38 families which are used to cure GI disorders were recorded and identified during the study. The descriptions of the plants have been depicted in table 1. Mode of preparation of drugs and their application against different GI disorders have been described in table 2 . Figure 2 has depicted the distribution of the plants recorded during the study according to their habit. Different parts of the plants are used against different GI disorders as depicted in figure 3. Numbers of different plants used against different GI disorders has been depicted in figure 4 .

Table 1. Descriptions of the plants identified during the study

\begin{tabular}{|c|c|c|c|c|c|}
\hline Sl. No. & Scientific name & Vernacular name & Family & Type & Parts used \\
\hline 1 & Aegle marmelos (L.) Corr. & Bel & Rutaceae & Tree & Fruit \\
\hline 2 & Alocasia indica (Roxb.) Schott & Man-kochu & Araceae & Herb & Corm \\
\hline 3 & Allium sativum L. & Naharu & Liliaceae & Herb & Bulb \\
\hline 4 & Aloe vera (L.) Burm. f & Salkonwari & Liliaceae & Herb & Leaf \\
\hline 5 & Amaranthus spinosus L. & Kata-Khutura & Amaranthaceae & Herb & Whole plant \\
\hline 6 & Averrhoa carambola L. & Kardoitenga & Oxalidaceae & Tree & Fruit \\
\hline 7 & Azadirachta indicaA. Juss. & Mahanim & Meliaceae & Tree & Leaf \\
\hline 8 & Boerhavia diffusa L. & Purnounouwa & Nyctaginaceae & Herb & Leaf and stem \\
\hline 9 & Calotropis gigantea (L.) R. Br & Aakan & Asclepiadaceae & Tree & Leaf \\
\hline 10 & Camellia sinensis L. kuntze & Chapat & Theaceae & Tree & Leaf \\
\hline 11 & Centella asiatica L. & Manimuni & Apiaceae & Herb & Whole plant \\
\hline 12 & Coriandrum sativum L. & Dhaniya & Apiaceae & Herb & Whole plant \\
\hline 13 & $\begin{array}{c}\text { Costus speciosus (Koen. ex Retz.) } \\
\text { Smith }\end{array}$ & Jamlakhuti & Costaceae & Herb & Rhizome \\
\hline 14 & Curcuma longa L. & Haladhi & Zingiberaceae & Herb & Rhizome \\
\hline 15 & Carica papaya L. & Amita & Caricaceae & Tree & Fruit \\
\hline 16 & Citrus limon (L.) Osbeck & Nemutenga & Rutaceae & Tree & Fruit \\
\hline 17 & Dillenia indica L. & Outenga & Dillaniaceae & Tree & Fruit \\
\hline 18 & Eclipta prostrate L. & Kehraj-bon & Asteraceae & Herb & Leaf \\
\hline 19 & Garcinia cowa Roxb. ex DC. & Kuji-thekera & Clusiaceae & Tree & Fruit \\
\hline 20 & Garcinia pedunculata Roxb. & Bor-thekera & Clusiaceae & Tree & Fruit \\
\hline 21 & Houttuynia cordata Thunb. & Machenderi & Saururaceae & Herb & Leaf \\
\hline 22 & Hydrocotyle sibthorpioides L. & Saru-manimuni & Apiaceae & Herb & Whole plant \\
\hline 23 & Hyptis suaveolens (L.) Poit. & Tokmah & Lamiaceae & Shrub & Seeds \\
\hline 24 & Ipomea mauritiana Jacq. & Bhui-komora & Convolvulaceae & Climber & Rhizome \\
\hline 25 & Justicia adhatoda L & Bahakatita & Acanthaceae & Shrub & Leaf \\
\hline
\end{tabular}


Table 1 Continuous

\begin{tabular}{|c|c|c|c|c|c|}
\hline 26 & Leea asiatica (L.) Rid. & Aiha bon & Liaceae & Herb & Root \\
\hline 27 & Leucas aspera (Willd.) Link & Doron-bon & Lamiaceae & Herb & Stem and leaf \\
\hline 28 & Mentha spicata L. & Pudinah & Lamiaceae & Herb & Whole plant \\
\hline 29 & Machilus bombycina King ex Hook. F. & Chom & Lauraceae & Tree & Leaf \\
\hline 30 & Marsilea minuta L. & Pani-tengechi & Marsileaceae & Herb & Whole plant \\
\hline 31 & Meyna spinosa Roxb. ex Link. & Moin & Rubiaceae & Tree & Leaf \\
\hline 32 & Momordica charantia L. & Titakerela & Cucurbitaceae & Climber & Fruit \\
\hline 33 & Moringa oleifera Lam. & Sajina & Moringaceae & Tree & Leaf, flower and fruit \\
\hline 34 & Murraya koenigii L. Sprengel & Narasingha & Rutaceae & Shrub & Leaf \\
\hline 35 & Musa paradisiaca L. & Bhimkol & Musaceae & Shrub & Body, Fruit \\
\hline 36 & Musa sapiantum L. & Kachkol/Pura kol & Musaceae & Shrub & Fruit \\
\hline 37 & Oxalis corniculata L. & Tengesitenga & Oxalidaceae & Herb & Whole plant \\
\hline 38 & Ocimum sanctum $\mathrm{L}$. & Tulsi & Lamiaceae & Shrub & Leaf \\
\hline 39 & Paderia scendens (Lour.) Merr. & Bhedailota & Rubiaceae & Climber & Leaf and stem \\
\hline 40 & Piper nigram L. & Jaluk & Piperaceae & Climber & Fruit \\
\hline 41 & Psidium guajava $\mathrm{L}$. & Madhuriaam & Myrtaceae & Tree & Fruit \\
\hline 42 & Phyllanthus emblica L. & Amlokhi & Phyllanthaceae & Tree & Fruit \\
\hline 43 & Punica granatum L. & Dalim & Lythraceae & Shrub & Fruit and leaf \\
\hline 44 & Solanum torvum Sw. & Tita-bhekuri, & Solanaceae & Shrub & Fruit \\
\hline 45 & Solanum ferox $\mathrm{L}$. & Saru-titabhekuri & Solanaceae & Shrub & Fruit \\
\hline 46 & Solanum lycopersicum L. & Bilahi & Solanaceae & Shrub & Fruit \\
\hline 47 & Spondias pinnata (L. f.) Kurz & Amora & Anacardiaceae & Tree & Fruit \\
\hline 48 & Swertia chirayita (Roxb. Ex Fleming) & Chirata & Gentianaceae & Tree & Leaf and stem \\
\hline 49 & Syzygium cumini (L.) Skeels & Kala-jamu & Myrtaceae & Tree & Fruit and bark \\
\hline 50 & Terminalia bellerica (Gaertn.) Roxb & Bhomora & Combritaceae & Tree & Fruit \\
\hline 51 & Terminalia chebula Retz. & Hilikha & Combretaceae & Tree & Fruit \\
\hline 52 & Vitex negundo L. & Posotiya & Verbenaceae & Shrub & Leaf \\
\hline 53 & Vigna mungo (L.) Hepper & Matimah & Fabaceae & Herb & Seed \\
\hline 54 & Vitex peduncularis Wall. & Ahoi & Verbenaceae & Herb & Root \\
\hline 55 & Zinziber officinale Roscoe & Ada & Zingiberaceae & Herb & Rhizome \\
\hline
\end{tabular}

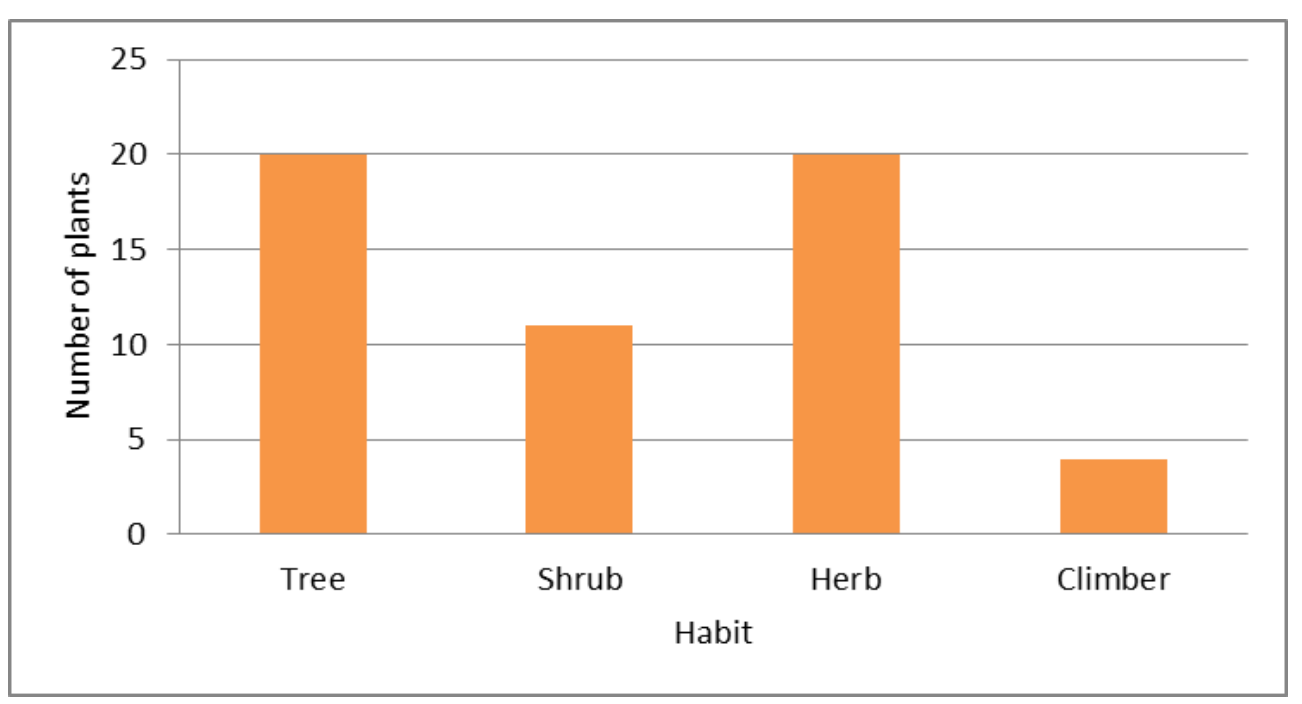

Figure 2. Distribution of plants according to their habit 


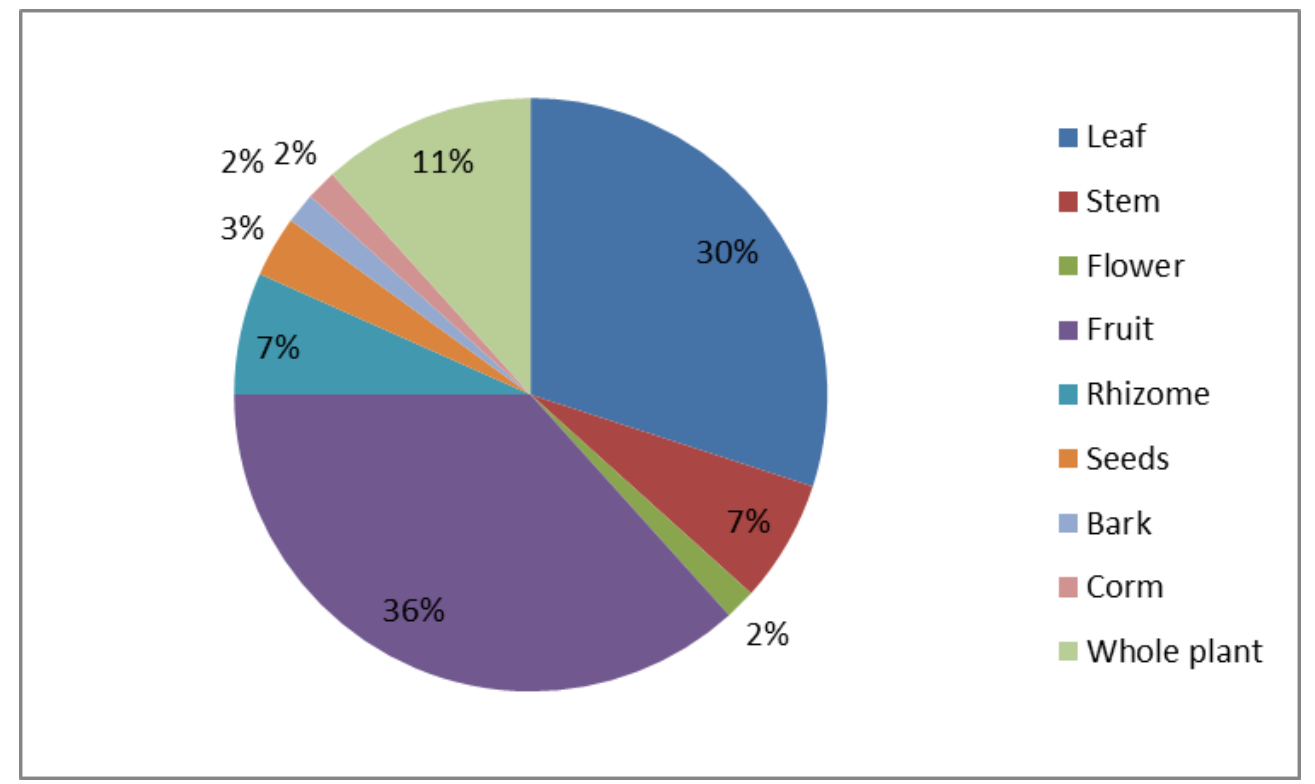

Figure 3. Different parts of plants used against different GI disorders

Table 2. Mode of preparation and dosage composition

\begin{tabular}{|c|c|c|}
\hline Name of the plant & Used against & Mode of preparation and dosage composition \\
\hline Aegle marmelos (L.) Corr. & Constipation & Ripe fruit is taken orally. \\
\hline $\begin{array}{l}\text { Alocasia indica (Roxb.) } \\
\text { Schott }\end{array}$ & $\begin{array}{c}\text { Jaundice } \\
\text { Liver disorder }\end{array}$ & Boiled or cooked corm is taken orally with boiled rice. \\
\hline Allium sativum L. & Indigestion & 2 or 3 pieces of bulb are taken orally with a glass of cold water. \\
\hline Aloe vera (L.) Burm.f & Acidity & One glass of leaf juice is taken orally once daily for 5-7 days. \\
\hline Amaranthus spinosus L. & $\begin{array}{c}\text { Jaundice } \\
\text { Diarrhoea }\end{array}$ & Cooked or boiled plants are taken orally. \\
\hline Averrhoa carambola $\mathrm{L}$. & $\begin{array}{l}\text { Jaundice } \\
\text { Dysentery }\end{array}$ & Cooked fruit is taken orally with boiled rice \\
\hline Azadirachta indica Juss. & $\begin{array}{c}\text { Worm } \\
\text { infestation }\end{array}$ & $\begin{array}{l}\text { 1-2 tea-spoon of leaf decoction is taken orally twice a day for a period of 7-10 } \\
\text { days. Sometimes, fresh leaf juice is also taken for effective result. }\end{array}$ \\
\hline Boerhavia diffusa $\mathrm{L}$. & $\begin{array}{l}\text { Indigestion } \\
\text { Jaundice } \\
\text { Dysentery } \\
\end{array}$ & Boiled or cooked leaves and stems are taken orally. \\
\hline $\begin{array}{l}\text { Calotropis gigantea (L.) } \\
\text { R. Br }\end{array}$ & Piles & $\begin{array}{l}\text { 3-4 leaves are crushed and the juice obtained is taken orally twice daily for one } \\
\text { month. }\end{array}$ \\
\hline $\begin{array}{l}\text { Camellia sinensis L. } \\
\text { kuntze }\end{array}$ & Dysentery & Leaf decoction is taken orally \\
\hline Centella asiatica L. & $\begin{array}{c}\text { Dysentery } \\
\text { Diarrhea } \\
\text { Bowl trouble } \\
\end{array}$ & Whole plant is grinded into paste or cooked and taken orally \\
\hline Coriandrum sativum L. & Indigestion & A paste is made by grinding the fresh plant and is taken orally with boiled rice. \\
\hline $\begin{array}{l}\text { Costus speciosus (Koen. } \\
\text { Ex Retz.) Smith }\end{array}$ & $\begin{array}{l}\text { Diabetes } \\
\text { Jaundice }\end{array}$ & $\begin{array}{l}\text { Rhizome is grinded into paste and taken orally by diabetic patient. } \\
\text { Rhizome is grinded into paste and } 50 \mathrm{ml} \text { of juice obtained from that paste is taken } \\
\text { and an equal amount of cow milk is added to it. This mixture is taken orally for a } \\
\text { period of 7-10 days once daily to get effective result against Jaundice. }\end{array}$ \\
\hline Curcuma longa $\mathrm{L}$. & $\begin{array}{c}\text { Dysentery } \\
\text { Abdominal ache } \\
\end{array}$ & Rhizome is grinded into paste and taken orally with or without honey. \\
\hline Carica papaya L. & $\begin{array}{l}\text { Constipation } \\
\text { Acidity }\end{array}$ & $\begin{array}{l}\text { Ripe fruit is useful against constipation. } \\
\text { Boiled or cooked fruit is taken orally with boiled rice for almost one month twice } \\
\text { daily to get rid of acidity. }\end{array}$ \\
\hline Citrus limon (L.) Osbeck & Acidity & Fruit juice is mixed with water and taken orally \\
\hline Dillenia indica $\mathrm{L}$. & $\begin{array}{c}\text { Diarrhea } \\
\text { Bowl trouble }\end{array}$ & Cooked fruit is taken orally with boiled rice. \\
\hline
\end{tabular}


Table 2. Continuous

\begin{tabular}{|c|c|c|}
\hline Eclipta prostrata L. & $\begin{array}{l}\text { Jaundice } \\
\text { Acidity }\end{array}$ & Leaves are grinded to paste and juice is taken orally \\
\hline $\begin{array}{l}\text { Garcinia cowa Roxb. Ex } \\
\text { DC. }\end{array}$ & $\begin{array}{l}\text { Dysentery } \\
\text { Digestive } \\
\text { disorder }\end{array}$ & $\begin{array}{l}\text { Ripe fruits are cut into slices and sun dried. 3-4 such slices are dipped into a glass } \\
\text { of cold water and kept it overnight. This water is then taken orally }\end{array}$ \\
\hline $\begin{array}{l}\text { Garcinia pedunculata } \\
\text { Roxb. }\end{array}$ & $\begin{array}{l}\text { Dysentery } \\
\text { Digestive } \\
\text { disorder } \\
\text { Jaundice }\end{array}$ & $\begin{array}{l}\text { Ripe fruits are cut into slices and sun dried. } 3-4 \text { such slices are dipped into a glass } \\
\text { of cold water and kept it overnight. This water is then taken orally }\end{array}$ \\
\hline $\begin{array}{l}\text { Houttuynia cordata } \\
\text { Thunb. }\end{array}$ & $\begin{array}{l}\text { Dysentery } \\
\text { Diarrhea } \\
\text { Bowl trouble }\end{array}$ & Fried leaves are taken orally with boiled rice. \\
\hline $\begin{array}{l}\text { Hydrocotyle } \\
\text { sibthorpioides L. }\end{array}$ & Bowl trouble & Cooked plants are taken orally. \\
\hline $\begin{array}{l}\text { Hyptis suaveolens (L.) } \\
\text { Poit. }\end{array}$ & Bowl trouble & Seeds are dipped in a glass of cold water and taken orally. \\
\hline Ipomea mauritiana Jacq. & Liver disorder & Rhizome is grinded into paste and taken orally for a week twice daily. \\
\hline Justicia adhatoda L & $\begin{array}{c}\text { Jaundice } \\
\text { Piles } \\
\end{array}$ & $\begin{array}{l}\text { 3-4 leaves are crushed and the juice is taken orally twice daily for a period of } \\
10-15 \text { days for Jaundice and a month or } 45 \text { days to get cure from piles. }\end{array}$ \\
\hline Leea asiatica (L.) Rid. & $\begin{array}{r}\text { Worm } \\
\text { infestation } \\
\text { Jaundice } \\
\end{array}$ & Roots are grinded to paste and taken orally \\
\hline $\begin{array}{l}\text { Leucas aspera (Willd.) } \\
\text { Link }\end{array}$ & Jaundice & Cooked leaves and stems are taken orally. \\
\hline Mentha spicata $\mathrm{L}$. & $\begin{array}{c}\text { Acidity } \\
\text { Bowl trouble } \\
\end{array}$ & Whole plants are grinded into paste and taken orally. \\
\hline $\begin{array}{l}\text { Machilus bombycina King } \\
\text { ex Hook. F. }\end{array}$ & Piles & 3-4 leaves are crushed and juice is taken orally for almost one month twice daily. \\
\hline Marsilea minuta L. & $\begin{array}{c}\text { Worm } \\
\text { infestation }\end{array}$ & Cooked plants are taken orally. \\
\hline $\begin{array}{l}\text { Meyna spinosa Roxb. Ex } \\
\text { Link. }\end{array}$ & $\begin{array}{c}\text { Dysentery } \\
\text { Bowl trouble } \\
\text { Liver disorder }\end{array}$ & Leaves are crushed and juice is taken orally. \\
\hline Momordica charantia L. & Diabetes & One glass of fruit juice is taken orally twice or thrice a week. \\
\hline Moringa oleifera Lam. & Diabetes & Cooked or fried fruits, flower and leaves are useful against diabetes. \\
\hline $\begin{array}{l}\text { Murraya koenigii L. } \\
\quad \text { Sprengel }\end{array}$ & $\begin{array}{l}\text { Constipation } \\
\text { Acidity } \\
\text { Bowl trouble }\end{array}$ & $\begin{array}{l}\text { Fresh leaves are made into paste and taken orally with boiled rice for } 5-7 \text { days. } \\
\text { Sometimes, fried or cooked leaves are also taken to get rid of the problem. }\end{array}$ \\
\hline Musa paradisiaca $\mathrm{L}$. & $\begin{array}{l}\text { Dysentery } \\
\text { Bowl trouble }\end{array}$ & $\begin{array}{l}\text { Ripe fruit is cut into slices and dipped into a glass of cold water and kept } \\
\text { overnight and the water is taken orally. } \\
\begin{array}{l}\text { 2-3 tea-spoon of the juice from the lower body part of the plant is taken orally for } \\
\text { a period of 3-5 days. }\end{array}\end{array}$ \\
\hline Musa sapiantum L. & Dysentery & Boiled fruit is taken orally with boiled rice. \\
\hline Oxalis corniculata L. & Bowl trouble & Cooked plants are taken orally. \\
\hline Ocimum sanctum $\mathrm{L}$. & Dysentery & $\begin{array}{l}\text { 7-10 fresh leaves along with equal number of leaves of Punica granatum L. and } \\
\text { Psidium guajava L. are crushed together and the juice obtained is taken orally twice } \\
\text { or thrice a day until recovery. }\end{array}$ \\
\hline $\begin{array}{l}\text { Paderia scendens (Lour.) } \\
\text { Merr. }\end{array}$ & $\begin{array}{c}\text { Dysentery } \\
\text { Bowl trouble }\end{array}$ & Cooked leaves and stems are taken orally with boiled rice. \\
\hline Piper nigram L. & Indigestion & $\begin{array}{l}\text { Mature fruits are dried and grinded to powder. } 1 \text { tea-spoon of this powder with } 1 \\
\text { tea-spoon of honey taken orally with a glass of lukewarm water }\end{array}$ \\
\hline Psidium guajava $\mathrm{L}$. & Dysentery & $\begin{array}{l}\text { 7-10 fresh leaves along with equal number of leaves of Punica granatum L. and } \\
\text { Ocimum sanctum L. are crushed together and the juice obtained is taken orally twice } \\
\text { or thrice a day until recovery. }\end{array}$ \\
\hline Phyllanthus emblica L. & $\begin{array}{l}\text { Indigestion } \\
\text { Acidity } \\
\text { Bowl trouble } \\
\text { Constipation } \\
\text { Stomach ulcer }\end{array}$ & $\begin{array}{l}\text { A powder is made from the dried fruits of this plant and mixed with the powder } \\
\text { made from dried fruits of Terminalia bellerica and Terminalia chebula. This } \\
\text { mixture is locally known as TRIFALA. 1-2 tea-spoon of TRIFALA is taken orally } \\
\text { with or without a glass of water. Sometimes, } 1 \text { tea-spoon of Curcuma longa powder } \\
\text { and } 1 \text { tea-spoon of honey are mixed with } 1-2 \text { tea-spoon of TRIFALA for effective } \\
\text { result against indigestion, acidity and constipation and stomach ulcer. }\end{array}$ \\
\hline
\end{tabular}


Table 2. Continuous

\begin{tabular}{|c|c|c|}
\hline Punica granatum L. & $\begin{array}{l}\text { Dysentery } \\
\text { Diarrhea }\end{array}$ & $\begin{array}{c}\text { 7-10 fresh leaves along with equal number of leaves of Ocimum sanctum L. and } \\
\text { Psidium guajava L. are crushed together and the juice obtained is taken orally twice } \\
\text { or thrice a day until recovery. }\end{array}$ \\
\hline Solanum torvum Sw. & $\begin{array}{l}\text { Worm } \\
\text { infestation } \\
\text { Bowl trouble }\end{array}$ & $\begin{array}{l}\text { 3-5 mature fruits are given orally to the child having infection early in the } \\
\text { morning for a period of 7-10 days. }\end{array}$ \\
\hline Solanum ferox $\mathrm{L}$. & $\begin{array}{c}\text { Worm } \\
\text { infestation }\end{array}$ & $\begin{array}{l}\text { 3-5 mature fruits are given orally to the child having infection early in the } \\
\text { morning for a period of 7-10 days. }\end{array}$ \\
\hline Solanum lycopersicum L. & Bowl trouble & Cooked or boiled fruits are taken orally. \\
\hline $\begin{array}{l}\text { Spondias pinnata (L. f.) } \\
\text { Kurz }\end{array}$ & $\begin{array}{c}\text { Dysentery } \\
\text { Bowl trouble }\end{array}$ & Cooked fruits are taken orally with boiled rice \\
\hline $\begin{array}{l}\text { Swertia chirayita (Roxb. } \\
\text { ex Fleming) }\end{array}$ & $\begin{array}{c}\text { Worm } \\
\text { infestation }\end{array}$ & $\begin{array}{l}\text { 3-4 pieces of stems of length 5-6 inch are dipped in a glass of cold water and kept } \\
\text { it overnight. 2-3 tea-spoon of that water is given to the child having infection orally } \\
\text { twice daily for 7-10 days. }\end{array}$ \\
\hline $\begin{array}{l}\text { Syzygium cumini (L.) } \\
\text { Skeels }\end{array}$ & Diabetes & $\begin{array}{l}\text { Ripe fruits are taken orally. } \\
\text { Bark is grinded into paste and 2-3 tea-spoon of the juice obtained from that paste } \\
\text { is taken orally once daily to control high blood glucose level. }\end{array}$ \\
\hline $\begin{array}{l}\text { Terminalia bellerica } \\
\text { (Gaertn.) Roxb }\end{array}$ & $\begin{array}{l}\text { Indigestion } \\
\text { Acidity } \\
\text { Bowl trouble } \\
\text { Constipation } \\
\text { Stomach ulcer } \\
\end{array}$ & $\begin{array}{l}\text { 1-2 tea-spoon of TRIFALA is taken orally with or without a glass of water. } \\
\text { Sometimes, } 1 \text { tea-spoon of Curcuma longa powder and } 1 \text { tea-spoon of honey are } \\
\text { mixed with 1-2 tea-spoon of TRIFALA and taken for a period of 20-30 days once } \\
\text { daily for effective result against stomach ulcer. }\end{array}$ \\
\hline Terminalia chebula Retz. & $\begin{array}{l}\text { Indigestion } \\
\text { Acidity } \\
\text { Bowl trouble } \\
\text { Constipation }\end{array}$ & $\begin{array}{l}\text { 1-2 tea-spoon of TRIFALA is taken orally with or without a glass of water. } \\
\text { Sometimes, } 1 \text { tea-spoon of Curcuma longa powder and } 1 \text { tea-spoon of honey are } \\
\text { mixed with 1-2 tea-spoon of TRIFALA for effective result. }\end{array}$ \\
\hline Vitex negundo L. & Bowl trouble & Boiled or cooked leaves are taken orally \\
\hline Vigna mungo (L.) Hepper & Bowl trouble & Boiled seeds are taken orally with boiled rice \\
\hline Vitex peduncularis Wall. & Jaundice & $\begin{array}{l}\text { Roots are grinded into paste and taken orally thrice a day for a period of 10-15 } \\
\text { days. }\end{array}$ \\
\hline Zinziber officinale Roscoe & $\begin{array}{c}\text { Indigestion } \\
\text { Bowl trouble }\end{array}$ & $\begin{array}{l}\text { Thin slices of rhizomes with normal salt are taken orally thrice a day for 2-3 days } \\
\text { for effective result. }\end{array}$ \\
\hline
\end{tabular}

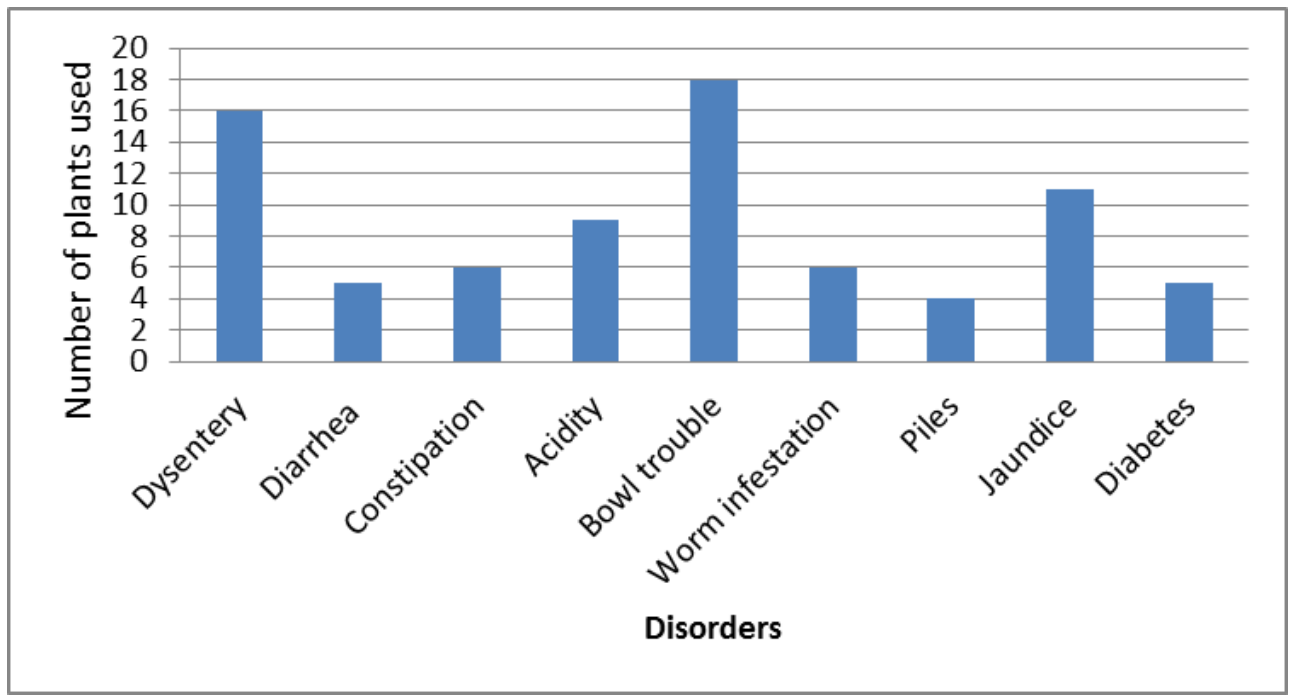

Figure 4. Different plants used against various GI disorders

\section{Discussion}

The evergreen state of Assam was proved to be a home for a large number of ethnobotanically important plant species by several reports. 107 numbers of plants were recorded by Das et. al. [14] used by the tribal people of
Cachar district of Assam against different human ailments. Hazarika et. al. [15] reported a total of 84 plant species belonging to 57 families used in medicinal purposes by the people of Assam and Manipur. A total of 85 plant species belonging to 49 families were recorded by Saikia et. al. [16] which are used by the Assamese people against 
skin related anomalies.

Several studies regarding the economically important plant species of Barpeta district of Assam were conducted by different researchers. According to a previous report, more than 750 plants species of economic importance have been recorded and identified from this region [10]. 57 plant species belonging to 36 families having medicinal value were identified and described by a study in the Manas National park situated near the study area [17].

The present study has documented the uses of 55 number of locally available plant species of the study area for treatment of various GI anomalies. It has been observed that most of the remedies consisted of single plant part and more than one method of preparation. Some of the remedies consist of different parts of the same plant to treat single or more diseases. However, in some cases, parts of two or even more different plants are used for curing a particular disease. For example, leaves of Ocimum sanctum L., Punica granatum L. and Psidium guajava $\mathrm{L}$. are crushed together to make a paste and the juice obtained from that paste is used against Dysentery. TRIFALA prepared by the combination of fruits of three plants viz., Phyllanthus emblica L., Terminalia bellerica (Gaertn.) Roxb and Terminalia chebula Retz is extensively used against a range of GI anomalies.

\section{Conclusion}

The present investigation has explored some of the traditionally used medicinal plants to cure various GI disorders from Barpeta district of Assam, North-East India. But, the efficiency of using these traditional medications cannot be judge properly without proper scientific exploration, although the people of the study area are using these plants effectively from long back. In spite of the availability and accessibility of the modern system of medication, most of the people of the study area still depend on herbal medication system provided by traditional drug practitioners. The need of the hour is to harness this traditional knowledge and to preserve this knowledge for the betterment of future mankind.

\section{Acknowledgement}

Authors acknowledge the immense help of local people especially the local drug practitioners from the study area during the study. We also acknowledge the Botany Department, Gauhati University and Botanical Survey of India, Eastern Circle, Shillong, Meghalaya, India for the help during identification of the specimens collected during the study.

\section{REFERENCES}

[1] Lewington, A. Medicinal plants and plant extracts: a review of their importation into Europe. Traffic International, Cambridge, UK. 1993.

[2] World health Organization. The Global burden of disease 2004; update. Geneva, WHO. Available at www.who.int/evidence/bod.

[3] Mao, A.A., Hynniewta, T.M. and Sanjappa, M. Plant wealth of Northeast India with reference to ethnobotany. Indian Journal of Traditional Knowledge. 8(1): 96-103. 2009.

[4] Chakraborty, R., De, B., Devanna, N. and Sen, S. North-East India an ethnic storehouse of unexplored medicinal plants. J Nat Prod Plant Resour. 2(1): 143-152, 2012.

[5] Sajem, A.L., Rout, J. and Nath, M. Traditional tribal knowledge and status of some rare and endemic medicinal plants of North Cachar Hills district of Assam, Northeast India. Ethnobotanical Leaflets, 12: 261-275. 2008.

[6] Laloo, R.C., Kharlukhi, L., Jeeva, S. and Mishra, B.P. Status of medicinal plants in the disturbed and the undisturbed sacred forests of Meghalaya, northeast India: population structure and regeneration efficacy of some important species. Current science. 90(2): 225-232. 2006.

[7] Dutta, B.K. and Dutta, P.K. Potential of ethnobotanical studies in North East India: An overview. Indian Journal of Traditional Knowledge. 4(1): 7-14. 2005.

[8] Bhattacharya, P.C., Muzumder, R. and Sarmah, G.D. Rare medicinal plants of Assam. Ancient science of life. 10(4): 234-238. 1991.

[9] National Informatics Center (NIC). District profile| Barpeta district| Government of Assam, India. https://barpeta.assam. gov.in/portlets/district-profile.(Accessed 5th November, 2020).

[10] Das, R., 2016. Biodiversity of Ethnomedicinal plants used by the ethnic tribal people of Barpeta district of Assam, North East India. Asian Journal of Pharmaceutical Science and Technology. 6(1): 27-32. 2016.

[11] Kanjilal UN, Kanjilal PC, Das A and Purkayastha C. Flora of Assam. Vol-I. Bishan Singh and Mahendra Pal Singh, Dehra Dun. 1934.

[12] Kanjilal UN, Kanjilal PC, De RN and Das A. Flora of Assam. Vol-IV. Bishan Singh and Mahendra Pal Singh, Dehra Dun. 1938.

[13] Bor, N.L. Flora of Assam. Vol. V. Gramineae. Government of Assam. 1940.

[14] Das, A.K., Dutta, B.K. and Sharma, G.D. Medicinal plants used by different tribes of Cachar district, Assam. Indian Journal of Traditional Knowledge. 7(3): 446-454. 2008.

[15] Hazarika, R., Abujam, S.S. and Neog, B. Ethno medicinal studies of common plants of Assam and Manipur. Int J Pharm Biol Arch. 3(4): 809-815. 2012.

[16] Saikia, A.P., Ryakala, V.K., Sharma, P., Goswami, P. and Bora, U. Ethnobotany of medicinal plants used by Assamese people for various skin ailments and cosmetics. Journal of Ethnopharmacology.106(2): 149-157. 2006. 
[17] Das, S., Khan, M.L., Rabha, A. and Bhattacharjya, D.K. Ethnomedicinal plants of Manas National Park, Assam,
Northeast India. Indian Journal of Traditional Knowledge. 8(4): 514-517. 2009. 